\title{
RELIGIONSRÖSTNING I SVERIGE 1988-2018
}

\author{
Magnus Hagevi, Institution för statsvetenskap, Linnéuniversitet \\ E-post I magnus.hagevi@1nu.se
}

\section{Inledning}

I en omfattande komparativ studie från slutet av 1960-talet konstaterade Richard Rose och Derek Urwin, till skillnad från allmänt vedertagna antaganden i tidigare forskning, att "[r]eligion, not class, is the main social base of parties in the Western world today." (Rose och Urwin 1969: 12). Därmed skulle religion vara den viktigaste sociala skiljelinjen i politiken, det vill säga det som identifierar olika samhällsgrupper med motstridiga politiska intressen (Lipset och Rokkan 1967). Ungefär samtidigt som Rose konstaterade religionens betydelse för röstning i Västvärlden slutade det svenska valforskningsprogrammet att undersöka religionsröstning (Holmberg och Gilljam 1987: 17; jfr Särlvik 1970; Petersson 1977). När dessa undersökningar ett par decennier senare åter studerade den religiösa faktorn vid röstning konstaterade Mikael Gilljam att klass var den starkaste socioekonomiska förklaringen till röstning i Sverige, fast "[ä]nnu 1985 framstår dock den religiösa faktorn som en icke oviktig förklaring till varför svenska väljare röstar som de gör." (Holmberg och Gilljam 1987: 210). I Sverige, precis som i andra europeiska länder, tenderade religiöst engagerade väljare att i större utsträckning rösta på borgerliga partier (Holmberg och Gilljam 1987), ett samband som senare studier bekräftat (Hagevi 2009). Gilljam noterade också att sambandet mellan religiöst engagemang och partival hade minskat från slutet av 1960-talet till mitten av 1980-talet (Holmberg och Gilljam 1987). Religionens minskade politiska betydelse är i linje med dealignment - att den politiska betydelsen av socioekonomiska skiljelinjer minskar och att socioekonomiska faktorer som klass och religion förklarar allt mindre av väljarnas partival 
(Dalton m fl 1984). I den omfattande forskningen om väljar-dealignment visar de flesta resultat att de sociala skiljelinjer, som en gång varit betydelsefulla, har minskat i betydelse (Dalton 2013; Oscarsson och Holmberg 2013). Detta kan sättas i samband med sekularisering, det vill säga att religion betyder allt mindre för allt fler människor och inom allt fler samhällsområden (Hagevi 2009). En sådan förändring implicerar bland annat att religiösa väljare i allt mindre utsträckning röstat på partier som traditionellt företräder dem. Vid sidan av denna förändring har andelen religiöst engagerade väljare minskat (Hagevi 2012), vilket minskar religiösa väljares inflytande över valresultaten.

Det finns forskare som menar att dealignment utmed religiösa skiljelinjer är mindre omfattande (Inglehart 1977: 217-225). För det första antas att familjesocialisationen är starkare för religion än för andra sociala skiljelinjer: föräldrarna tros vara mer måna om att föra över värden och åsikter knutna till religion jämfört med till exempel klass. För det andra innebär sekularisering ett ifrågasättande av religiösa värden, vilket kan aktivera religiösa väljare politiskt och stärka sambandet mellan religiöst engagemang och partival. I svenskt sammanhang kan ett sådant exempel vara Kristdemokraternas nationella genombrott 1991 och att partiet sedan dess varit representerade i riksdagen. Partiets mobilisering av religiösa väljare kan vara en extra injektion för svensk religionsröstning (Hagevi 2005).

Vid flera tillfällen har den svenska befolkningen beskrivits som en av världens mest sekulära befolkningar (Norris och Inglehart 2013), samtidigt har samma befolkning beskrivits som en av Europas mest mångreligiösa (Sorgenfrei 2019). En del forskare vill inte tala om sekularisering utan om religiös förändring: svenskarna har gått från att vara kyrkobesökare till att bli privatreligiösa (Davie 2000; Hagevi 2012). Andra forskare menar att det svenska samhället har gått in i en postsekulär tid (Brommesson och Friberg-Fernros 2013; Halldorf 2018). Fenomen som sekularisering och annan religiös och politisk förändring är processer som äger rum på sikt och som därför bör belysas genom att jämföra förhållandet mellan religiositet och politik över tid. Detta gör det extra intressant att söka ett svar på frågan: Har religionsröstningen försvagats bland svenska väljare under de senaste tre decennierna? Med fokus på utvecklingen sedan 1988 kommer denna artikel besvara tre frågeställningar.

1. På vad sätt har svenskarnas religionsutövning förändrats vad gäller religiöst engagemang i form av gudstjänst och bön?

2. Har sambandet mellan svenskarnas partival och gudstjänstbesök försvagats?

3. Har sambandet mellan svenskarnas partival och böneaktivitet försvagats?

I det följande diskuteras först teorier om hur religiositet kan påverka röstning följt av ett avsnitt som presenterar studiens data, variabler och statistiska mått. Därefter redovisas det förändrade religiösa engagemanget bland svenska befolkningen de tre senaste decennierna. Sedan beskrivs sambandet mellan gudstjänstbesökare och partival följt av en beskrivning av sambandet mellan bön och partival. Till sist presenteras studiens huvudslutsatser. 


\section{Hur religiositet kan påverka röstning}

Det finns ingen dominerande definition av religion. Bland substantiella definitioner är det inte ovanligt att karaktärisera religion som trossystem, symboler, beteenden normer och/eller gemenskaper vilka är relaterade till en perception av en transcendent verklighet bredvid den naturliga (Hagevi 2017). Studier om religion försöker förklara vad religion är och skilja det från andra fenomen för att studera religionens teologiska innehåll, förelagda utövande eller dess uppkomst. Studier av religiositet intresserar sig däremot för individens religiösa trossystem, värden och beteenden (Gustafsson 2000). I det följande är religiositet individens subjektiva perception av och/eller beteende knutet till en transcendent verklighet bredvid den naturliga (Hagevi 2009).

Forskning har konstaterat att det är vanligt att påstå att religion och politik inte hör ihop (Jensdotter 2018). En sådan normativ ståndpunkt har dock mött kritik (se t ex Bjereld och Brommesson 2007; Brommesson och Friberg-Fernros 2013). Föreliggande studie intresserar sig inte för normativa ställningstaganden om relationen mellan religion och politik. Istället riktas fokus på hur människors religiositet har samband med politik när de röstar. Utifrån teorin om gruppsocialisation kan väljarnas religiositet påverka såväl deras politiska tänkande - kognition som deras politiska känslor - affektion. Den kognition och affektion som rör individens förhållande till både religion och politik kan teoretiskt relateras till socialisationsprocesser som förekommer i sociala grupper. Om socialisationen sker i en religiös grupp (till exempel i en kyrka eller en religiös familj) är det möjligt att det inte enbart är religiösa uppfattningar som individen tar till sig, utan att det även finns politiska inslag som påverkar partival.

Enligt den traditionella standardbeskrivningen av socialisation - vilken jag använder - är socialisation en omfattande och uthållig introduktion till de normer som strukturerar beteendet $\mathrm{i}$ den sociala grupp som en individ är eller vill vara medlem av. Individen erhåller på så sätt en identitet med gruppen; vederbörande har en subjektiv uppfattning om sig själv som tillhörig gruppen och individen delar dess intressen och framtida öden. Utifrån tankarna om den egna gruppens intressen och framtid kan identitet sättas samman med kognition. En framgångsrik religiös socialisation resulterar i en stark religiös identifikation. Graden av religiös identifikation signaleras av individens religiösa engagemang, det vill säga religionsutövningens intensitet, till exempel hur ofta någon besöker gudstjänster eller ber till Gud. För att bibehålla sin religiösa identitet är individen beroende av särskilda stödjande strukturer som finns i sociala grupper, så kallad plausibilitetsstruktur. Ju mer frekvent och intensiv kontakten med sådana stödjande sociala grupper är, desto mer troligt är det att individen har kvar sin identitet. Till exempel kan en religiös person ha större möjlighet att bevara sin religiösa identitet om han eller hon regelbundet deltar i en kyrkas gudstjänst. Gudstjänstbesök är alltså en indikator på att individen är har ett positivt engagemang för sin religion (Hagevi 2009).

Religiöst engagemang antas kunna påverka politisk opinion då individen socialiseras till att anpassa sig till de strukturer som finns i olika sociala grupper: familj, vänner, kyrka, arbetskamrater etcetera. För att bli accepterad som medlem i en social grupp måste individen anta samma beteenden, trosuppfattningar och värden som de andra gruppmedlemmarna har. I den mån 
religiöst engagemang är relaterat till trosuppfattning och värden kan religiösa väljares tänkande om politik knytas till psykologisk kognitionsforskning (Zaller 1992). I denna forskning antas människor ha en begränsad kapacitet för att behandla information samtidigt som de är "kognitiva latmaskar" som gärna undviker att använda sin mentala kapacitet (Taylor 1981). För att göra det så lätt som möjligt att tänka använder människor därför vad som blivit kallat för kognitiva genvägar (heuristics). Kognitiva genvägar hjälper individer att behandla den information som finns runt omkring dem (Kuklinski och Quirk 2000). Bland religiöst engagerade används religiös övertygelse oftare som ett sådant hjälpmedel än bland mer sekulära väljare (Hagevi 2009). Religiösa kognitiva genvägar kan hjälpa en väljare med att förstå vad som är politik, vad som kan ignoreras och genast glömmas bort eller vad som är värt att uppmärksamma samt bestämma om ett politiskt förslag är bra eller dåligt (Price 1992). Till exempel kan väljarna jämföra politiska ståndpunkter med religiösa kognitiva genvägar. Ett parti som väljaren uppfattar ha ståndpunkter som bäst överensstämmer med dessa kognitiva genvägar kan då erhålla den religiösa väljarens röst. Med ökat religiöst engagemang borde en religiös kognitiv genväg vara mer aktiverad än bland mer sekulära väljare och användas mer för att tänka om politik (Zaller 1992). Människor som är religiöst engagerade borde bland annat därför i större utsträckning rösta efter religiösa kognitiva genvägar än vad som är fallet med mer sekulära väljare. För att agera politiskt räcker det dock inte med tankar, utan forskningen visar att känslor - affektion - är viktigt för att fă väljare att utföra politiska handlingar (Marcus 2003; Redlawsk 2006). Utan känslor stannar politiken. Religiöst engagemang kan också indikera i vad mån en människa har starka känslor för en religion (Hagevi 2009).

Utifrån gruppsocialisation och socialkognitionsforskning kan religiositet påverka hur människor känner för och tänker om politik. Därmed kan religiöst engagemang påverka partival. Under antagandet att gudstjänstbesök och bön indikerar religiöst engagemang kan det således ha samband med väljarnas partival.

\section{Data, variabler och statistiska mått}

Avsikten är att studera religiöst engagemang och partival bland svenska väljare. För att kunna uttala sig om detta behövs data. Religiöst engagemang studeras genom gudstjänstbesök och bön. Det finns givetvis många andra sätt att undersöka religiöst engagemang (Leege och Kellstedt 1993). De nu använda måtten på religiöst engagemang är inriktade på beteende, medan det finns andra mått som är mer psykologiska. Fördelen att analysera religiöst engagemang med gudstjänstbesök är att detta kan knytas till teoretiska antaganden om socialisation där affektion respektive kognition är viktiga element. Till skillnad från gudstjänst är bön ett beteende som inte alltid genomförs tillsammans med andra människor. En sådan religionsutövning kan därför indikera privatreligiositet (Hagevi 2012). Gudstjänstbesök är dessutom en religionsutövning som till stor del är relaterad till kristendom. Surveyinstitutet vid Linnéuniversitetet visar i frågeundersökningen Survey 2018 (Hagevi 2020) att av de som minst en gång i månaden besöker gudstjänst identifierar sig 88 procent som kristna, medan 5 procent identifierar som muslimer $(n=104)$. Bland de som i samma undersökning ber till Gud minst en gång i månaden identifierar sig 79 procent som kristna och 8 procent som muslimer $(n=281)$. 
Studiens data är vetenskapliga frågeundersökningar av svenska väljare och svenska befolkningen. Det är två sorters sådana data som används. För det första studeras väljarnas gudstjänstbesök och röstning genom SVT-valu 1991-2018. SVT-valu är en vallokalsundersökning som genomförs av Sveriges television i samarbete med Göteborgs universitet och Kungliga tekniska högskolan (Oscarsson m fl 2018). Vid ett urval av röstställen ombeds väljarna att fylla i en enkät när de lämnar vallokalen. Vid valet 1991 besvarade drygt 2700 personer enkäten, i valen 1994-1998 var antalet svarande ungefär 7000-9000 personer och 2002-2018 var antalet svaranden ungefär 11000-13000 personer. Enkäten behandlar bland annat hur svarspersonerna röstat och hur ofta de besöker gudstjänst. Frågan om gudstjänstbesök lyder: "Hur ofta brukar Du gå till gudstjänst eller på möte i någon kyrka/religiöst samfund?" med svarsmöjligheterna "Minst en gång i månaden", "Några gånger om året", "Mera sällan" och "Aldrig”. Ju oftare väljaren besöker gudstjänst, desto större antas individens religiösa engagemang vara.

Väljarnas partival undersöks med frågan "Vilket parti röstade på i dag i riksdagsvalet?" De svarsmöjligheter som ingår i föreliggande analys är partier som haft riksdagsrepresentation under undersökningsperioden samt de partier som erhållit mer än tre procent av rösterna i tidsmässigt näraliggande riksdagsval. Väljare som röstat på andra partier analyseras i kategorin "övriga partier”. Genom att vid två tillfällen (1991 och 1998) använda frågan om hur väljaren röstade i föregående riksdagsval är det möjligt att dels förlänga tidserien till 1988 samt erhålla data om sambandet mellan gudstjänstbesök och partival 1994 (då väljarnas gudstjänstbesök inte undersöktes i SVT-valu). Frågan om hur väljarna röstade i föregående riksdagsval lyder: Vilket parti röstade Du på i förra riksdagsvalet [1988 eller 1994]?

För det andra studeras gudstjänstbesök, böneaktivet och partisympati genom de frågeundersökningar som genomförts av SOM-institutet vid Göteborgs universitet mellan 19882018 (SOM-institutet 2019). Dessa frågeundersökningar genomförs i form av postenkäter riktade till representativa urval av svenska befolkningen mellan 16-75/80/85 år (den övre åldersgränsen har succesivt höjts i undersökningarna). I SOM-undersökningar studeras religiöst engagemang genom gudstjänstbesök och bön. Denna typ av religiöst engagemang undersöks i ett frågebatteri som inleds med följande fråga: "Hur ofta har Du under de senaste 12 månaderna gjort följande saker?" Därefter nämns bland annat "Besökt gudstjänst eller religiöst möte" och "Bett till Gud". I båda fallen är svarsalternativen "Ingen gång", "Någon gång under de senaste 12 månaderna", "Någon gång i halvåret", "Någon gång i kvartalet", "Någon gång i månaden", "Någon gång i veckan" samt "Flera gånger i veckan". Dessa uppgifter analyseras på två sätt. För det första som en skala från 1 ("Ingen gång") till 7 ("Flera gånger i veckan"). För det andra delas svaren i tre kategorier: aldrig ("Ingen gång"), sällan (från "Någon gång under de senaste 12 månaderna" till "Någon gång i kvartalet") och regelbundet (från "Någon gång i månaden" till "Flera gånger i veckan"). SOM-institutet har inte undersökt böneaktivitet alla åren 1988-2018: åren 1989-1994 och 1996-1997 saknar uppgift om svarspersonen bett till Gud. Då SOM-institutet delvis undersöker gudstjänstbesök och bön i olika enkätformulär skiftar inte bara antalet svarande beroende på undersökningsår, utan även mellan de båda typerna av religiöst engagemang: ungefär 1500-3500 svarande för gudstjänstbesök och ungefär 1500-10500 svarande för bön. 
I SOM-undersökningarnas undersöks partisympati genom frågan "Vilket parti tycker Du bäst om idag?" Även nu beaktas undersökningsperiodens riksdagspartier och de som samlade minst tre procent av rösterna i närliggande riksdagsval. Väljare som röstade på andra partier samlas i kategorin "övriga partier". Notera att SOM-institutet genomför sina undersökningar varje år, inte bara vid riksdagsval. Därför analyseras inte svarspersonernas röstning utan deras partisympatier, något som väljarna kan redovisa även när det inte är val.

De mått som används är procent och Cramers V. Det sistnämnda är ett sambandsmått som kan användas för variabler på nominalnivå, vilket är fallet för partival. Måttet går från 0 (inget samband) till 1 (perfekt samband) och ju högre värde, desto starkare samband mellan variablerna (måtten på religiöst engagemang och partival). Sambanden mellan religiöst engagemang och partival analyseras utan viktningar i urvalet.

\section{Förändrat religiöst engagemang bland svenska väljare}

En del forskare antar att sekulariseringen tilltar med samhällets modernisering (Bruce 2002). I figur 1 och 2 redovisas andelen gudstjänstbesökare mellan 1988-2018 enligt SVT-valu respektive SOM-undersökningarna.

Figur 1: Hur ofta en person brukar besöka gudstjänst eller religiöst möte (procent).

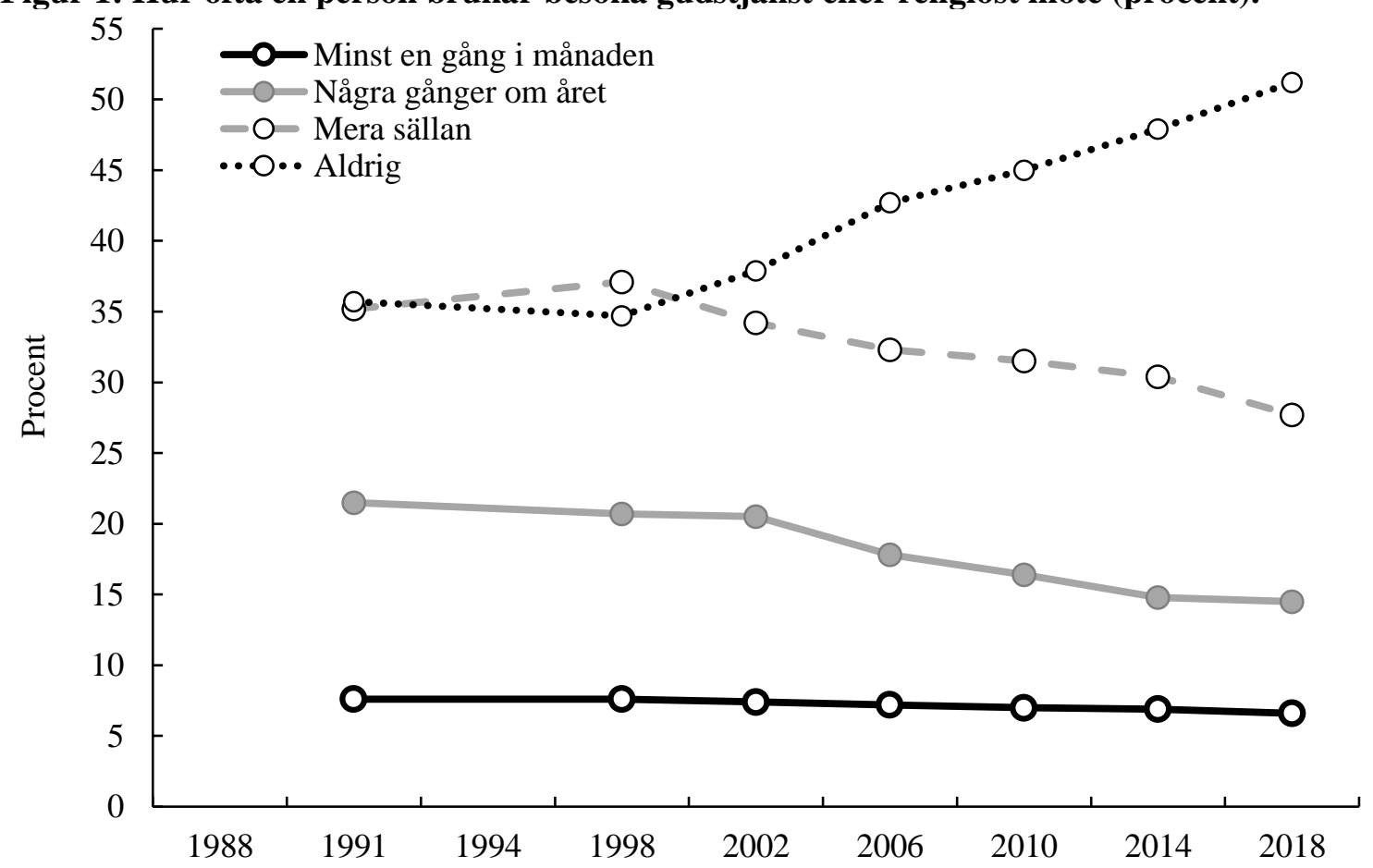

Kommentar: Data från SVT-valu. Frågan löd: "Hur ofta brukar Du gå till gudstjänst eller på möte i någon kyrka/religiöst samfund?" Det var möjligt att svara "Minst en gång i månaden", "Några gånger om året", "Mera sällan" och "Aldrig". 
Figur 2: Hur ofta en person besökt gudstjänst eller religiöst möte under en ettårsperiod, 1988-2018 (procent).

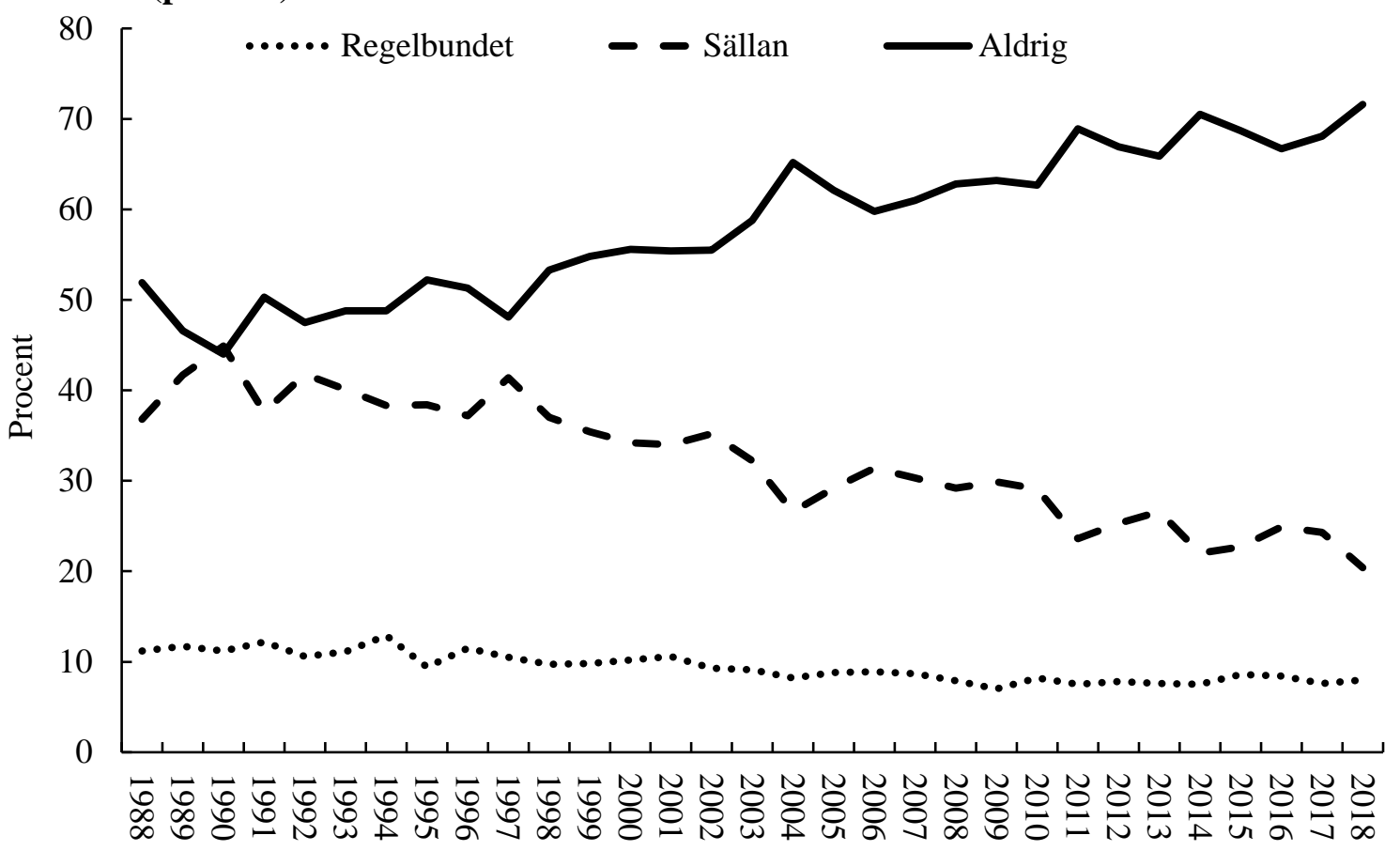

Kommentar: Data från SOM-institutet. Frågan löd: "Hur ofta har du under de senaste 12 månaderna gjort följande?", varpå bland annat "Besökt gudstjänst eller religiöst möte" nämndes. Det var möjligt att svara "Ingen gång" (kategoriserad som "aldrig"), " Någon gång under de senaste 12 månaderna", "Någon gång i halvåret", "Någon gång i kvartalet" (dessa tre svar kategoriserade som "sällan"), "Någon gång i månaden", "Någon gång i veckan" och "Flera gånger i veckan" (dessa tre svar kategoriserade som "regelbundet").

Trots olika urvalsmetoder och frågeformuleringar överensstämmer förändringen i andelen gudstjänstbesökare till stor del mellan de båda undersökningarna. De mest engagerade gudstjänstbesökarna är en liten men tämligen stabil andel, men med en svag minskning. Däremot ökar andelen som aldrig besöker gudstjänst på bekostnad av de som då och då går på gudstjänst. Sedan 1988 består gudstjänstsekulariseringen främst av en ökad andel som inte har kontakt med kyrkor och religiösa organisationer på bekostnad av andelen vars motsvarande kontakt var tämligen sporadisk. I båda mätningarna accentueras ökningen av de som aldrig besöker gudstjänst efter 1998.

I figur 3 redovisas andelen som ber till Gud. Till skillnad från gudstjänstbesök är detta en religionsutövning som kan ske enskilt, utan religiös organisering. Därmed kan bön vara ett mått som även beaktar privatreligiositet. Medan gudstjänstbesök i stor utsträckning är en kristen religionsutövning (Hagevi 2015) är bön dessutom ett mer mångreligiöst mått på religiöst engagemang. 
Figur 3: Hur ofta en person bett till Gud under en ettårsperiod, 1988-2018 (procent).

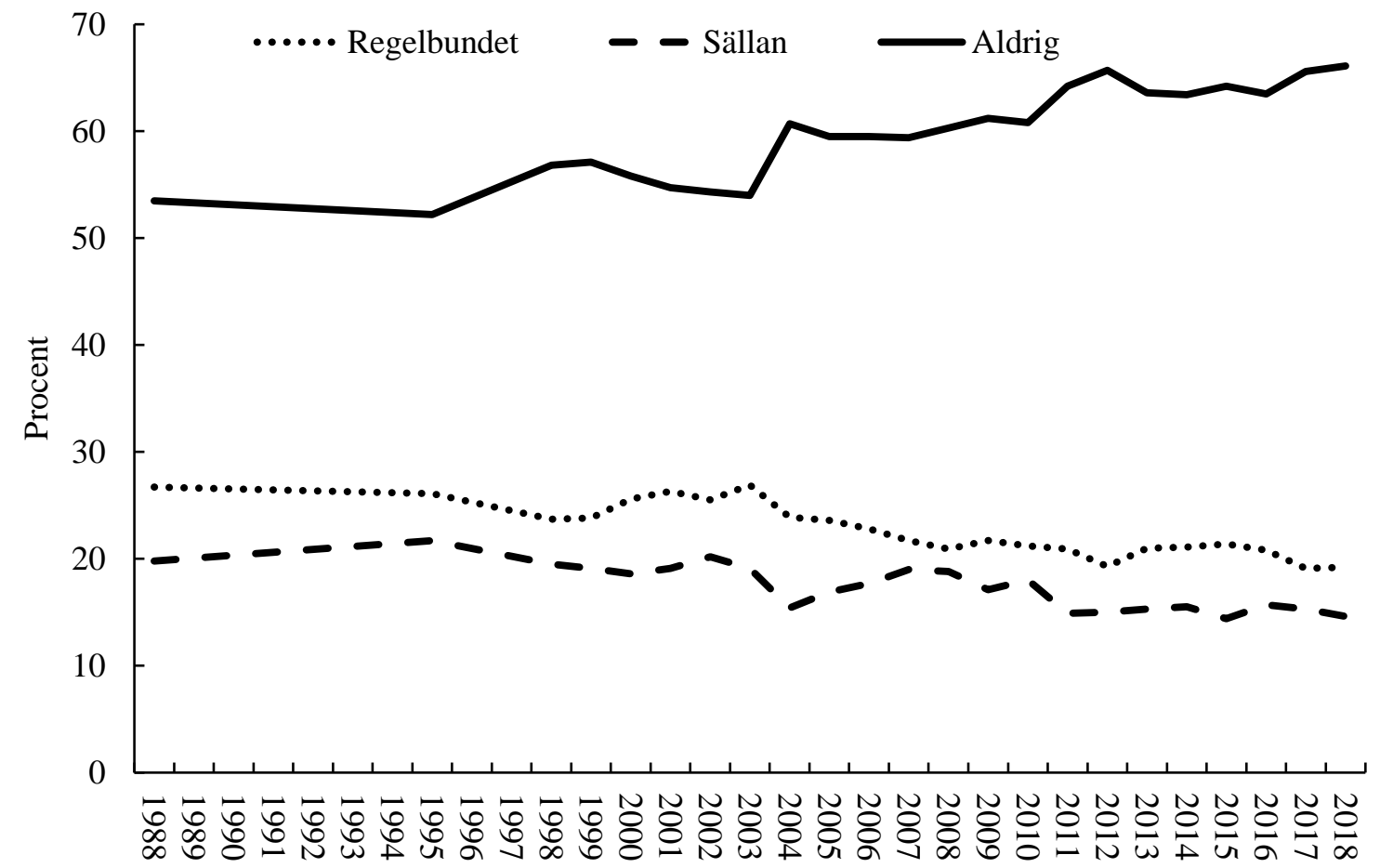

Kommentar: Frågan löd: "Hur ofta har du under de senaste 12 månaderna gjort följande?", varpå bland annat "Bett till Gud" nämndes. Det var möjligt att svara "Ingen gång" (kategoriserad som "aldrig"), " Någon gång under de senaste 12 månaderna", "Någon gång i halvåret", "Någon gång i kvartalet" (dessa tre kategoriserade som "sällan"), "Någon gång i månaden", "Någon gång i veckan" och "Flera gånger i veckan" (dessa tre svar kategoriserade som "regelbundet").

Det är fler i den svenska befolkningen som ber regelbundet (minst en gång i månaden) än som lika regelbundet deltar i gudstjänst. Också vad gäller bön ökar andelen som aldrig ber från slutet av 1990-talet. Men till skillnad från gudstjänstbesök leder detta till att såväl andelen personer som ber regelbundet som sällan minskar.

Både gudstjänstbesök och böneaktivitet visar på ett minskat religiöst engagemang $\mathrm{i}$ en stor grupp av befolkningen. I den mån religiöst engagemang visar på religionens betydelse i människors liv betyder det att religionens politiska betydelse också minskar för allt fler väljare. Att inte vara religiöst engagerad är dock ett val som kan vara förbundet med politiska åsikter och politiskt beteende (Hagevi 2010), varför frånvaro av religion också kan ge politiska effekter.

\section{Samband mellan gudstjänstbesök och partival}

Vad gäller religiöst engagemang och röstning är gudstjänstbesök det som intresserat tidigare forskare mest (Rose och Urwin 1969; Gilljam och Holmberg 1987; Hagevi 2009; Dalton 2013). I figur 4 redovisas sambandet mellan gudstjänstbesök och partival 1988-2018. Den svarta linjen markerar sambandet mellan gudstjänstbesök och svenska väljares röstning enligt SVT-valu och den grå linjen markerar sambandet mellan gudstjänstbesök och svenska befolkningens 
partisympatier enligt SOM-institutet. Sambandsmåttet är Cramers V som varier mellan 0 (inget samband) och 1 (perfekt samband). Ju högre värde Cramers V visar, desto starkare är sambandet mellan gudstjänstbesök och partival.

Figur 4: Samband mellan gudstjänstbesök och partival, 1988-2018 (Cramers V).

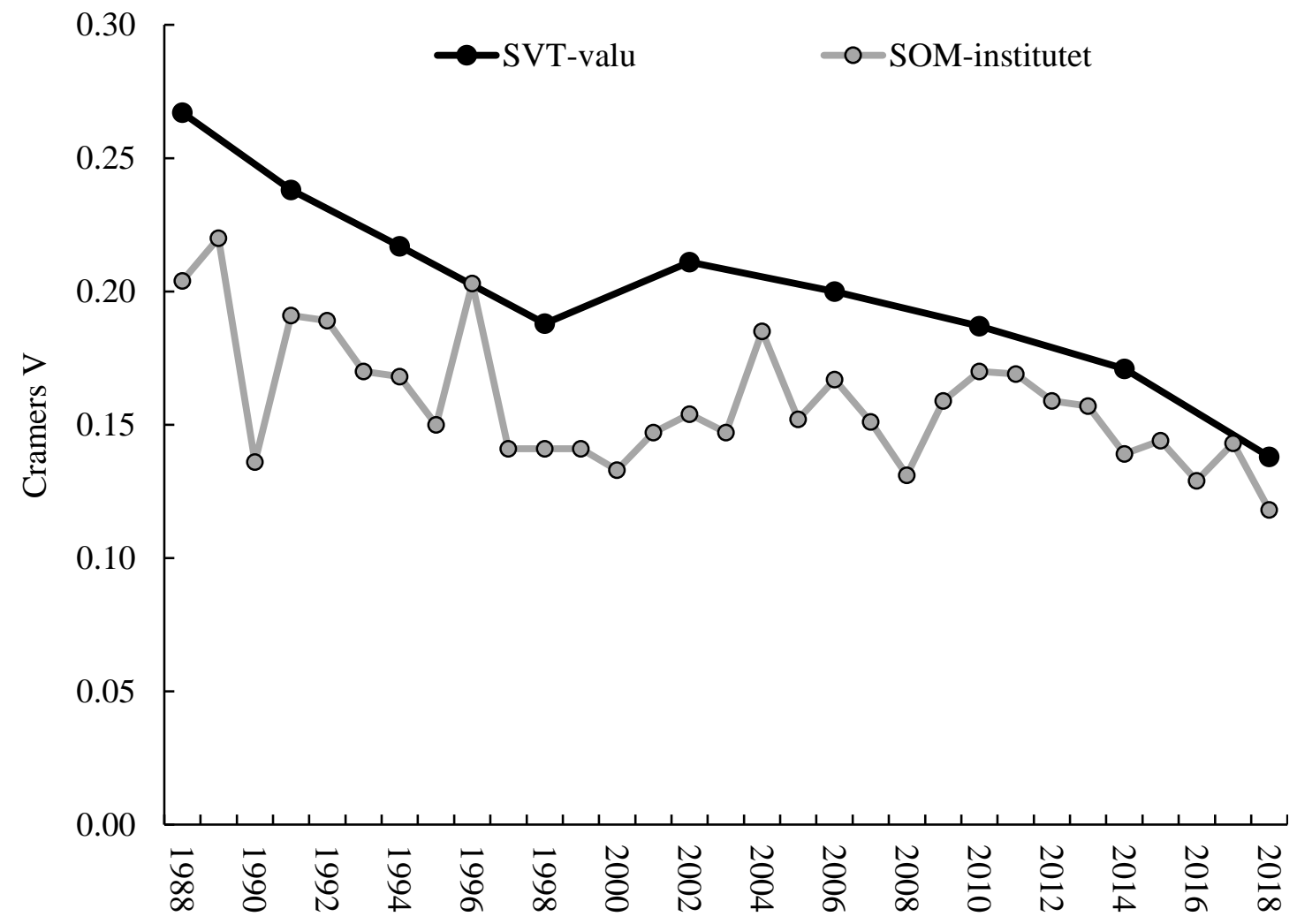

Kommentar: I SVT-valu undersöks röstning genom frågan "Vilket parti röstade på i dag $\mathrm{i}$ riksdagsvalet?", undantaget 1988 och 1994 då minnesuppgifter från 1991 respektive 1998 används: "Vilket parti röstade Du på i förra riksdagsvalet [1988/1994]?" I SOM-institutet undersöks partisympati genom frågan "Vilket parti tycker Du bäst om idag?" I SVT-valu löd frågan om gudstjänstbesök: "Hur ofta brukar Du gå till gudstjänst eller på möte i någon kyrka/religiöst samfund?" Svarsmöjligheterna var "Minst en gång i månaden", "Några gånger om året", "Mera sällan" och "Aldrig". I SOM-institutet löd frågan om gudstjänstbesök: "Hur ofta har du under de senaste 12 månaderna gjort följande?", varpå bland annat "Besökt gudstjänst eller religiöst möte" nämndes. Det var möjligt att svara "Ingen gång", " Någon gång under de senaste 12 månaderna", "Någon gång i halvåret", "Någon gång i kvartalet", "Någon gång i månaden", "Någon gång i veckan" och "Flera gånger i veckan".

Enligt SVT-valus och SOM-institutets undersökningar tenderar sambandet mellan människors gudstjänstbesök och partival att minska. Minskningen är mer distinkt i SVT-valus undersökningar som rör röstande i riksdagsvalen, men i SOM-undersökningarna om partisympati, som också genomförs mellan valen, är sambandet något otydligare. När endast valår studeras blir tendensen för SOM-institutets samband mellan gudstjänstbesök och partisympati mer lik motsvarande samband enligt SVT-valu. Det är därmed möjligt att det skett en mobilisering under valår som inneburit en förstärkt religionsröstning. Denna mobiliseringseffekt tycks dock ha avtagit över tid, 
då sambanden mellan gudstjänstbesök och partival enligt SVT-valu och SOM-institutet blir mer lika varandra över tid. Eftersom båda undersökningarna i huvudsak visar samma resultat styrks slutsatsen att sambandet mellan gudstjänstbesök och partival avtagit över tid. Detta överensstämmer med att sociala skiljelinjers betydelse minskar i politiken (Dalton 2013).

\section{Samband mellan böneaktivitet och partisympati}

Medan gudstjänstbesök till stor del är en kristen religionsutövning förlagd till kyrkor förekommer bön mer allmänt $\mathrm{i}$ de flesta religioner samt är något som kan utövas enskilt även bland personer som kan betraktas som privatreligiösa (Hagevi 2012). I den mån som försvagningen av sambandet mellan religiöst engagemang och partival är ett fenomen knutet till kristna kyrkor kan därför en undersökning av sambandet mellan böneaktivitet och partival ge ett annat resultat. I figur 5 redovisas sambandet mellan böneaktivitet och partisympati mellan 1988 och 2018. Även nu används sambandmåttet Cramers V.

Figur 5: Samband mellan böneaktivtet och partival, 1988-2018 (Cramers V).

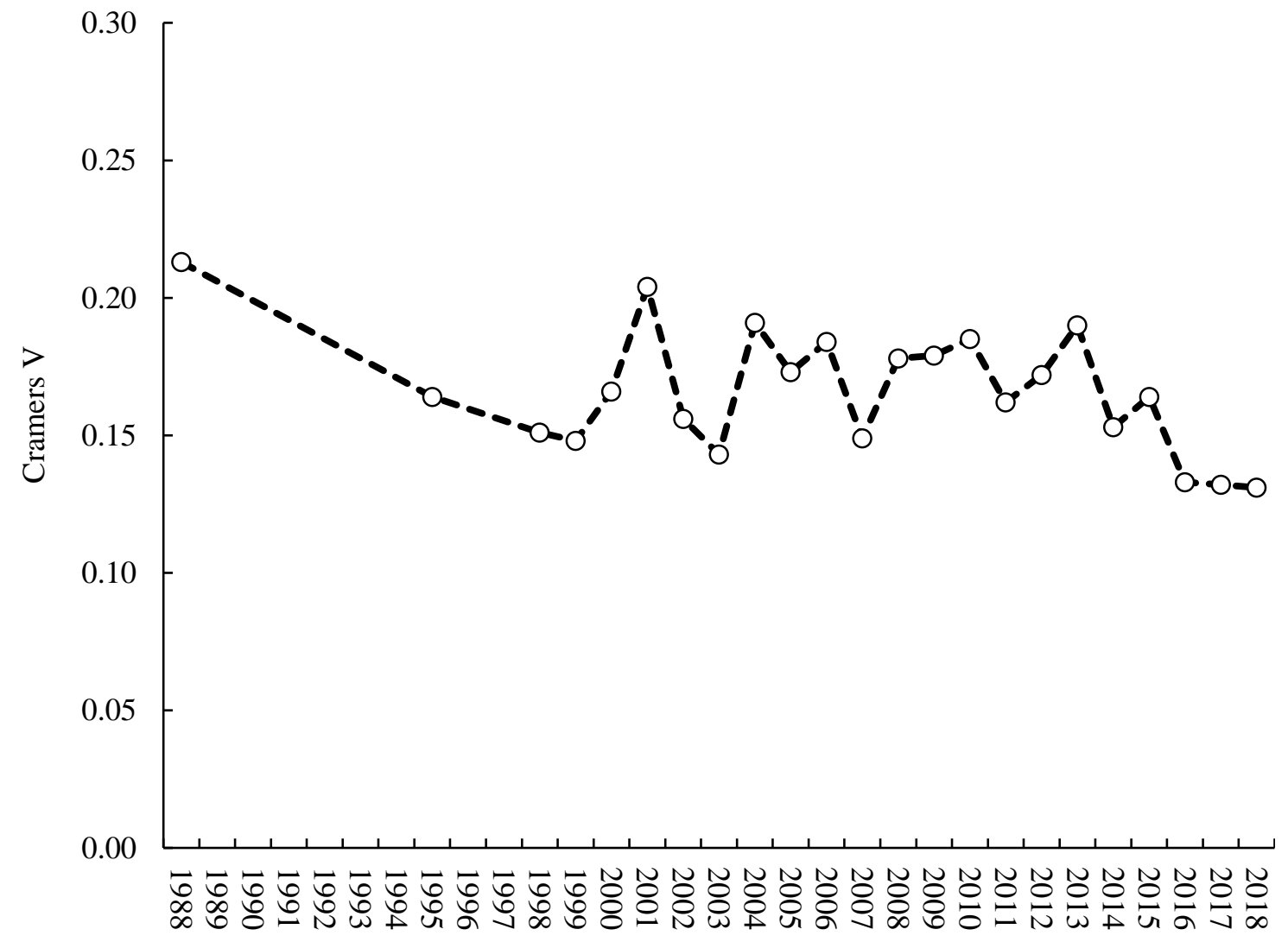

Kommentar: I SOM-institutet undersöks partisympati genom frågan "Vilket parti tycker Du bäst om idag?" I SOM-institutets undersökning löd frågan om gudstjänstbesök: "Hur ofta har du under de senaste 12 månaderna gjort följande?", varpå bland annat "Bett till Gud" nämndes. Det var möjligt att svara "Ingen gång", " Någon gång under de senaste 12 månaderna", "Någon gång i halvåret", "Någon gång i kvartalet", "Någon gång i månaden", "Någon gång i veckan" och "Flera gånger i veckan". 
Liksom för gudstjänstbesök är det möjligt att notera att sambandet mellan böneaktivitet och partisympati försvagas över tid. Även nu blir tendensen av ett försvagat samband tydligare när endast valår studeras. Resultatet styrker slutsatsen att det är en generell försvagning av sambandet mellan religiöst engagemang och partival, inte bara kyrkoreligiositet, som ägt rum mellan 1988 och 2018. Därmed bekräftas också den i Västvärlden vanligt förekommande utvecklingen som innebär att sociala skiljelinjer betyder allt mindre inom politiken.

\section{Slutsatser om förändrad religionsröstning}

Huvudslutsatsen i denna studie är att religionsröstningen har försvagats bland svenska väljare under de senaste tre decennierna. Svenskarnas religionsutövning har minskat vad gäller gudstjänstbesök och bön. Det är främst andelen personer som mer sporadiskt besökt gudstjänster som minskat medan andelen som aldrig kommer till gudstjänst har blivit fler. Andelen regelbundna gudstjänstbesökare är istället tämligen stabil. Även andelen personer som aldrig ber har ökat, men vad gäller bön har både andelen sporadiska bedjare som sällan ber och mer regelbundna bedjare minskat. Resultatet styrker antaganden om en fortgående sekularisering av den svenska befolkningen. En sådan sekularisering innebär i sig att betydelsen för den religiösa faktorn minskar i politiken i den meningen att allt färre utövar religion.

Sambandet mellan svenskarnas religiösa engagemang och partival har försvagats mellan 1988 och 2018. Minskningen är mer distinkt vad gäller väljarnas röstande i riksdagsvalen, men något mindre tydlig när undersökningen vid sidan av valår även beaktar partisympati under mellanvalår. I den mån det skett en mobilisering som inneburit att religionsröstningen förstärkts i samband med riksdagsval har denna mobiliseringseffekt avtagit över tid.

Bön är en aktivitet som gudstjänstbesökare, utövare av olika religioner och privatreligiösa kan ägna sig åt. Även sambandet mellan böneaktivitet och partival har försvagats mellan 1988 och 2018. Det innebär att sambandet mellan religiöst engagemang och partival minskat överlag och att det inte är begränsat till kyrkoreligiositet. Därmed bekräftas den i Västvärlden vanligt förekommande utvecklingen som innebär att sociala skiljelinjer betyder allt mindre inom politiken (Dalton 2013).

Resultaten i denna studie överensstämmer med den process som kallas sekularisering: att religionens betydelse minskar inom allt fler samhällssektorer och för att fler människor (Hagevi 2017). Dels därför att andelen religiöst engagerade minskar. Dels för att religiöst engagemang i allt mindre utsträckning påverkar den politiska samhällssektorn då religionsröstningen minskar i Sverige.

\section{Referenser}

Bjereld, Ulf och Douglas Brommesson (2007) Politik och kristen tro: Två berättelser. Stockholm: Santérus. 
Brommesson, Douglas och Henrik Friberg-Fernros (2013) Bortom den sekulära staten: Religion och politik $i$ en postsekulär tid. Lund: Studentlitteratur.

Bruce, Steve (2002) God is Dead: Secularization in the West. Oxford: Blackwell Publishing.

Dalton, Russell J. (2013) Citizen Politics: Public Opinion and Political Parties in Advanced Industrial Democracies. Washington, DC: CQ Press.

Dalton, Russell J, Scott C Flanagan och Paul Allen Beck, red (1984) Electoral Change in Advanced Industrial Democracies: Realignment or Dealignment? Princeton: Princeton University Press.

Davie, Grace. 2000. Religion in Modern Europe: A Memory Mutates. Oxford: Oxford University Press.

Gustafsson, Göran (2000) Tro, samfund och samhälle. Sociologiska perspektiv. Örebro: Libris.

Hagevi, Magnus (1996) "Religiositet och första valet till EU-parlamentet" s 89-107 i

Västsvenska perspektiv (SOM-rapport: 17), red Lennart Nilsson. Göteborg: SOM-institutet, Göteborgs universitet.

Hagevi, Magnus (2005) "Evangelikaler i svensk och amerikansk politik", s 134-162 i Religion och politik, red Magnus Hagevi. Malmö: Liber.

Hagevi, Magnus (2009) Politisk opinion och religiositet $i$ Västra Götaland. Lund: Sekel.

Hagevi, Magnus (2012) "Beyond Church and State: Private Religiosity and Post-Materialist

Political Opinion among Individuals in Sweden.” Journal of Church and State, 54 (4): 499-525.

Hagevi, Magnus (2015) Den svenska väljaren 2014. Malmö: Gleerups.

Hagevi, Magnus (2017) "Religious Change over the Generations in an Extremely Secular Society: The Case of Sweden." Review of Religious Research, 59 (4): 499-518.

Hagevi, Magnus (2020, kommande) ”Survey 2018: Teknisk rapport.” Surveyjournalen, 7 (1).

Holmberg, Sören och Mikael Gilljam (1987). Väljare och val i Sverige. Stockholm: Bonniers.

Inglehart, Ronald (1977). The Silent Revolution: Changing Values and Political Styles Among Western Publics. Princeton: Princeton University Press.

Jensdotter, Linnea (2018, kommande) Religion och politik i hybrida mediemiljöer: Diskussioner om religion och politik i kommentarer till artiklar om Miljöpartiet, Kristdemokraterna, och Sverigedemokraterna på Facebook. Uppsala: Acta Universitatis Upsaliensis.

Kuklinski, James och Paul Quirk (2000) "Reconsidering the Rational Public: Cognition, Heuristics, and Mass Communicatin"s 153-182 i Elements of Reason: Cognition, Choice, and 
Bounds of Rationality, red Arthur Lupia, Matthew McCubbins och Samuel Popkin. Cambridge: Cambridge University Press.

Leege, David och Lyman Kellstedt, red (1993) Rediscovering the Religious Factor in American Politics. Armonk: M. E. Sharpe.

Lipset, Seymour M. och Stein Rokkan (1967) "Cleavage Structures, Party Systems, and Voter Alignments: An Introduction", s 1-64 i Party Systems and Voter Alignments, red Seymour Lipset och Stein Rokkan. New York: The Free Press.

Marcus, George (2003) "The Psychology of Emotions and Politics", s 182-221 i Oxford Handbook of Political Psychology, red David Sears, Leonie Huddy och Robert Jervis. Oxford: Oxford University Press.

Norris, Pippa and Ronald Inglehart (2013) Sacred and Secular: Religion and Politics Worldwide. Cambridge: Cambridge University Press.

Oscarsson, Henrik och Sören Holmberg (2013) Nya svenska väljare. Stockholm: Norstedts juridik.

Oscarsson, Henrik Ekengren, Per Näsman, Eva Landahl och Sören Holmberg (2018) VALU 2018 - SVT:s vallokalsundersökning riksdagsvalet 2018. Stockholm: Sveriges Television AB

Petersson, Olof (1977) Väljarna och valet 1976. Stockholm: Statistiska centralbyrån/Liber.

Price, Vincent (1992) Public Opinion. Newbury Park: Sage Publications.

Rose, Richard och Derek Urwin (1969), "Social Cohesion, Political Parties and Strains in Regimes." Comparative Political Studies, 2 (1): 7-67.

Redlawsk, David, red (2006) Feeling Politics: Emotions in Political Information Processing. New York: Palgrave MacMillan.

Sorgenfrei, Simon. 2019. "Vi måste prata om Sverige som mångreligiöst land." Dagens Arena, nr 17 (hämtad 2020-03-03: https://www.dagensarena.se/essa/vi-maste-prata-om-sverige-sommangreligiost-land/).

SOM-institutet (2019) Super-Riks-SOM 1986-2018 (v2019.1). Göteborg: SOM-institutet, Göteborgs universitet.

Särlvik, Bo (1970) "Socioeconomic Position, Religious Behavior, and Voting in the Swedish Electorate: An Application of Computerized Classification Techniques." Quality and Quantity, 4 (1): 95-116.

Taylor, Shelly (1981) "The Interface of Cognitive and Social Psychology", s 189-211 i Cognition, Social Behavior, and the Environment, red John Harvey. Hillsdale: Erlbaum,.

Zaller, John (1992) The Nature and Origins of Mass Opinion. Cambridge: Cambridge University Press. 